\title{
Modulation of Hippocampal Acetylcholine Release: A Potent Central Action of Interleukin-2
}

\author{
Uwe-Karsten Hanisch, David Seto, and Rémi Quirion \\ Douglas Hospital Research Centre, Department of Psychiatry, and Department of Pharmacology and Therapeutics, \\ McGill University, Montreal, Québec, H4H 1R3 Canada
}

The potential of the T-cell growth factor interleukin-2 (IL-2) to modulate the release of $\mathrm{ACh}$ from rat hippocampus was studied in vitro, as a means to investigate the possible functional significance of this cytokine in the CNS. Hippocampal slices were superfused with Krebs' buffer medium, and endogenous ACh released into the superfusate was measured using a radioenzymatic assay. Recombinant human IL-2 present during a stimulation with $25 \mathrm{~mm} \mathrm{KCI}$ altered, in a concentration-dependent manner, the evoked transmitter release. At a concentration of $15 \mathrm{U} / \mathrm{ml}$ ( $\leq 1 \mathrm{nM}$ ), IL-2 inhibited ACh release by more than $50 \%$ of the control level (evoked $A C h$ release from the untreated contralateral hemispheres). Inhibition was observed within $\mathbf{2 0}$ min of tissue exposure to IL-2 and lasted for up to $1 \mathrm{hr}$. The inhibitory effect of IL-2 was reversible since transient tissue exposure to IL-2 did not affect subsequent evoked ACh release. IL-2 at this concentration also significantly decreased evoked $\mathrm{ACh}$ in frontal cortical slices, but was ineffective in the parietal cortex and striatum, revealing that IL-2 selectively modulates the release of ACh from certain, but not all, cholinergic nerve terminals in the CNS. At very low concentrations $(1.5 \mathrm{mU} /$ $\mathrm{ml}, \leq 0.1 \mathrm{pM}), \mathrm{IL}-2$ transiently increased hippocampal evoked ACh release, resulting in a biphasic dose-response profile with no significant effect observed at $0.015 \mathrm{mU} / \mathrm{ml}(\leq 1 \mathrm{fM})$. Other cytokines (IL-1 $\alpha, \mathrm{IL}-3, \mathrm{IL}-5, \mathrm{IL}-6$, interferon $\alpha$ ), tested in hippocampal slice incubations, failed to modulate $\mathrm{ACh}$ release. These results suggest that the immunoregulator IL-2 is a potent and selective modulator of ACh release in selected regions of the rat brain, an effect apparently not shared with other cytokines. The potent action of IL-2 on ACh release most likely relates to the discrete distribution of IL2(-like) antigen and ${ }^{125} \mathrm{I}-\mathrm{IL}-2$ binding sites in rat brain tissues (Lapchak et al., 1991).

[Key words: interleukin-2, cytokines, neuromodulation, transmitter release, $\mathrm{ACh}$, hippocampus]

Cytokines are signaling peptides of the immune system. Interleukin-2 (IL-2) was one of the first cytokines to be characterized in detail (for a review, see Hatekayama and Taniguchi, 1991). IL-2 is predominantly synthesized by antigen- or mito-

\footnotetext{
Received Sept. 30, 1992; revised Jan. 15, 1993; accepted Feb. 4, 1993.

This work was supported by the Medical Research Council of Canada and by the Fonds de Recherche en Sante du Québec (FRSQ). U.-K.H. is a recipient of a fellowship of the Human Frontier Science Program. D.S. and R.Q. are holders of studentship and Chercheur-Boursier awards from the FRSQ, respectively.

Correspondence should be addressed to Dr. Rémi Quirion, Douglas Hospital Research Centre, Lehmann Pavillon, 6875 Boulevard Lasalle, Montréal, Québec H4H 1R3, Canada.

Copyright (C) 1993 Society for Neuroscience $0270-6474 / 93 / 133368-07 \$ 05.00 / 0$
}

gen-activated $\mathrm{T}$-cells and regulates, as an autocrine/paracrine growth hormone, their clonal expansion. IL-2, in conjunction with antigen, mitogen, or anti-immunoglobulin antibodies, also controls B-cell proliferation and differentiation into antibodysecreting cells. Furthermore, by acting on cytolytic T-lymphocytes, and natural killer (NK) and lymphokine-activated killer cells, IL-2 participates in the activation of cytotoxic immune responses. These diverse immunoregulatory functions are mediated by specific interactions with cell membrane IL-2 receptors (IL-2R), which are composed of two moieties, IL-2R $\alpha / \mathrm{p} 55$ / Tac and IL-2R $\beta / \mathrm{p} 70$, respectively (Kuziel and Greene, 1990; Waldmann, 1991). IL-2R $\alpha$ and IL-2R $\beta$ bind IL-2 with low $\left(k_{D}\right.$ $\left.\approx 10^{-8} \mathrm{M}\right)$ and moderate $\left(k_{D} \approx 10^{-9} \mathrm{M}\right)$ affinity; upon activationinduced association to the noncovalent $\alpha \beta$-heterodimer they form the high-affinity IL-2 receptor complex $\left(k_{D} \approx 10^{-11} \mathrm{M}\right)$. Other putative components of the receptor/effector complex are predicted that may control ligand binding and receptor-mediated IL-2 endocytosis, in addition to enzymatic activities involved in IL-2-triggered signal transduction(s). Because of its potent immunostimulatory properties, IL- 2 has been introduced as an anti-tumor drug (for review, see Rosenberg, 1990) and is now clinically used in various immunotherapeutic strategies.

IL-2, among other cytokines, may also act as a neuromodulator in the CNS. Regulatory functions in the nervous tissue have been proposed, for example, for the growth and differentiation of glial and neuronal cells as well as for the control of neuronal activity in the hippocampus, locus coeruleus, and certain hypothalamic nuclei (for a review, see Merrill, 1990, 1991; Nisticò and De Sarro, 1991; Plata-Salamán, 1991). As a modulator of the neuroendocrine system, IL-2 can directly alter the release of pituitary hormones (Karanth and McCann, 1991). The presence of biological activities as well as II -2(-like) immunoreactive material (IRM), IL-2R-associated IRM, IL-2 mRNA, and ${ }^{125}$ I-IL-2 binding sites has been demonstrated in the rodent and, partly, in the human brain, under normal and pathophysiological conditions (Nieto-Sampedro and Chandy, 1987; Luber-Narod and Rogers, 1988; Araujo et al., 1989; Merrill, 1990; Lapchak et al., 1991; Villemain et al., 1991). Moreover, IL-2-induced disruption and penetration of the bloodbrain barrier has been subject to experimental studies and clinical observation (Ellison et al., 1987, 1990; Saris et al., 1988; Alexander et al., 1989; Watts et al., 1989; Banks et al., 1991; Ellison and Merchant, 1991). It thus appears that effects of IL-2 in the brain could be due to the genuine existence of IL-2(-like) peptides intrinsic to the CNS, or to elevated blood-borne IL-2.

Elevated amounts of peripheral IL-2 in patients undergoing high-dose IL-2 immunotherapy are reflected by IL-2 concentrations in the cerebrospinal fluid reaching up to $9 \mathrm{U} / \mathrm{ml}$ (Saris 
et al., 1988). At these concentrations, IL-2 immunotherapy is accompanied by a variety of side effects, including adverse neurologic symptoms such as memory impairments (Denicoff et al., 1987; Plata-Salamán, 1991). The hippocampus, a brain structure enriched with IL-2/IL-2R IRM, ${ }^{125}$ I-IL-2 binding sites (Lapchak et al., 1991), and IL-2 mRNA (Villemain et al., 1991), is most probably involved in certain aspects of memory and therefore one of the likely targets of CNS-directed IL-2 activities. Of the various neurotransmitters present in the hippocampal formation, $\mathrm{ACh}$ is the candidate that has most often been related to learning and memory.

The objective of the present study was thus to investigate the potential of IL-2 to modulate ACh release in the rat hippocampal formation using in vitro brain slice superfusion. The results indicate that $\mathrm{IL}-2$ is able to modify in a concentration-dependent manner $\mathrm{ACh}$ release in the hippocampus. Its minimal effective dose being in the (sub)picomolar range, it demonstrates that IL-2 is one of the most potent modulators of ACh release characterized so far. This effect seems to be specific, since various other cytokines tested failed to alter ACh release.

Parts of the results have recently been presented in abstract form (Seto et al., 1991).

\section{Materials and Methods}

Male albino Sprague-Dawley rats (300-325 gm) were obtained from Charles River (breeding colony St. Constant, Quebec, Canada). Recombinant human IL-2 (rhIL-2), frequently shown to be effective in the rat CNS (see Karanth and McCann, 1991), was from Sigma Chemical Co. (catalog number T-3267; St. Louis, MO). Interferon $\alpha$ (rhIFN $\alpha$ ) was from Janssen/Cedarlane Laboratories (Hornby, Ontario, Canada). All other cytokines, in the human recombinant form (IL- $\alpha$, IL-3, IL-5, and IL-6), were obtained from Upstate Biotechnology (Lake Placid, NY). Adenosine triphosphate (ATP), dithiothreitol, and bovine serum albumin (BSA) were from Boehringer Mannheim (Laval, Quebec, Canada); choline kinase (ATP:choline phosphotransferase, EC 2.7.1.32), acetylcholinesterase type V-S (acetylcholine hydrolase, EC 3.1.1.7), acetylcholine chloride, physostigmine sulfate, and Amberlite CG-400 (chloride form) were from Sigma Chemical Co. (St. Louis, MO); tetraphenylboron and butyronitrile were from Aldrich Chemical Co. (Milwaukee, WI): $\gamma$ - ${ }^{32}$ P-ATP $(2-10 \mathrm{mCi} / \mathrm{mmol})$ was from New England Nuclear (Mississauga, Ontario, Canada); Ecolite was from ICN (Montreal, Quebec, Canada). All other chemicals were of analytical grade and purchased from Fisher Scientific (Montreal, Quebec, Canada).

Tissue preparation and release studies. Rats were decapitated and the brains were removed into chilled Krebs' buffer medium (KBM) composed of (in mM) NaCl, $120 ; \mathrm{KCl}, 4.6 ; \mathrm{CaCl}_{2}, 2.4 ; \mathrm{KH}_{2} \mathrm{PO}_{4}, 1.2 ; \mathrm{MgSO}_{4}$, 1.2 ; D-glucose, $9.9 ; \mathrm{NaHCO}_{3}, 25 ;$ saturated with $\mathrm{O}_{2} / \mathrm{CO}_{2}(95 \%: 5 \%)$, and adjusted to $\mathrm{pH} 7.4$. Tissue regions (hippocampus, striatum, frontal, or parietal cortex) were rapidly dissected on ice and sliced at $400 \mu \mathrm{m}$ intervals with a McIlwain tissue chopper. Slices of one hemisphere were immediately placed in a superfusion chamber, built according to Richter (1976), and superfused at a rate of $0.5 \mathrm{ml} / \mathrm{min}$ with $\mathrm{KBM}$ containing choline chloride $(10 \mu \mathrm{M})$, to support synthesis of $\mathrm{ACh}$, and physostigmine ( $30 \mu \mathrm{M}$ for the hemisulfate), to prevent enzymatic degradation of $\mathrm{ACh}$. The buffer reservoir was continuously bubbled with $\mathrm{O}_{2} / \mathrm{CO}_{2}(95 \%$ : $5 \%$ ) mixture. The temperature of the chambers and the medium was kept at $37^{\circ} \mathrm{C}$. After $45 \mathrm{~min}$, superfusate fractions (10 or $20 \mathrm{~min}$ each) were collected. Aliquots were spun in a microcentrifuge (Biofuge B 13, Heareus, $13,000 \mathrm{rpm}, 3 \mathrm{~min}$ ), and $1.3 \mathrm{ml}$ of the supernatant was stored at $-70^{\circ} \mathrm{C}$ until further processing. Tissue slices were stimulated with $\mathrm{KBM}$ containing $25 \mathrm{mM} \mathrm{KCl}\left(\mathrm{K}^{+} \mathrm{KBM}\right)$, with equimolar reduction in $\mathrm{NaCl}$, in the presence of IL-2. Controls were stimulated in parallel with $\mathrm{K}^{+} \mathrm{KBM}$ omitting the interleukin. At the end of the superfusion, tissue slices were removed from the chambers and protein content was measured in triplicate according to Lowry et al. (1951), using BSA dissolved in $\mathrm{KBM}$ as a standard.

Evoked release of $\mathrm{ACh}$ from hippocampal slices was also determined in tissue incubations carried out according to Araujo et al. (1989). Briefly, hippocampal slices $(300 \mu \mathrm{m})$ were incubated at $37^{\circ} \mathrm{C}$ in $\mathrm{KBM}(1 \mathrm{ml})$ for $70 \mathrm{~min}$, with changes of the medium after 30 and $60 \mathrm{~min}$. Subse- quently, slices of one hemisphere were incubated in $1.35 \mathrm{ml}$ of $\mathrm{KBM}$ containing BSA $(1 \mathrm{mg} / \mathrm{ml})$ and one of the following cytokines: IL- $1 \alpha$, IL-3, IL-5, IL-6, or IFN $\alpha$. After $20 \mathrm{~min}$, the slices were incubated for another $20 \mathrm{~min}$ with the cytokine dissolved in $\mathrm{K}^{+} \mathrm{KBM}$ containing BSA $(1 \mathrm{mg} / \mathrm{ml})$. As controls, slices from the contralateral hemisphere were treated in parallel, but in the absence of the cytokine. Supernatants and tissues were separated by centrifugation and treated as described for the superfusions.

Determination of $A C h$. ACh was determined using a radioenzymatic assay (Goldberg and McCaman, 1973). Briefly, ACh was extracted from samples by mixing an aliquot of $400 \mu \mathrm{l}$ with an equal volume of tetraphenylboron in butyronitrile ( $10 \mathrm{gm} / \mathrm{liter})$. Separation of the phases was completed by centrifugation (Biofuge B 13, Heareus, 13,000 rpm, 4 $\mathrm{min}$ ); $300 \mu$ l of the organic phase was removed and shaken $(4 \mathrm{~min}$ ) with a half-volume of $\mathrm{AgNO}_{3}$ solution $(20 \mathrm{gm} / \mathrm{liter})$. The mixture was spun (Biofuge B 13, Heareus, 13,000 rpm, $4 \mathrm{~min}$ ), and $110 \mu \mathrm{l}$ of the aqueous phase was placed in a new tube containing $10 \mu \mathrm{MgCl}_{2}$ solution (1 M). After shaking and spinning, $100 \mu \mathrm{l}$ of the supernatant was transferred into a glass tube and evaporated. The pellet was dissolved in $32 \mu \mathrm{l}$ of a reaction mixture composed of choline kinase $(0.005 \mathrm{U})$, ATP $(0.8$ $\mathrm{mM}), \mathrm{MgCl}_{2}(12.5 \mathrm{mM})$, and dithiothreitol ( $5 \mathrm{~mm}$ ) in glycylglycine buffer $(25 \mathrm{~mm}, \mathrm{pH} 8.0)$. Following $30 \mathrm{~min}$ of incubation at $30^{\circ} \mathrm{C}, 10 \mu \mathrm{l}$ of ${ }^{32} \mathrm{P}$ ATP solution $(0.45 \mu \mathrm{Ci})$ containing acetylcholinesterase $(2 \mathrm{U})$ was added to the sample. The mixture was incubated for another $30 \mathrm{~min}$ at $30^{\circ} \mathrm{C}$. The reactions were terminated by addition of $100 \mu \mathrm{l} \mathrm{NaOH}$ (50 mm). As a result, only the choline derived from $\mathrm{ACh}$ was ${ }^{32} \mathrm{P}$-phosphorylated. The samples were placed on glass pipette columns filled with Amberlite CG-400 (approximately $800 \mu$ l bed volume) that was converted to its formate form and equilibrated with $\mathrm{NaOH}(50 \mathrm{~mm})$. The columns were rinsed with $3 \mathrm{ml}$ of $\mathrm{NaOH}(50 \mathrm{~mm})$ to elute any phosphocholine, while excessive ${ }^{32} \mathrm{P}$-ATP (accounting for more than $99 \%$ of the activity added) was retained on the column. The eluate, collected in scintillation vials, was mixed with scintillation cocktail, and radioactivity was measured by liquid scintillation spectrometry. Standards of ACh chloride ( $0-400$ pmol in $400 \mu \mathrm{l}$ of KBM) were processed in parallel. All determinations were carried out in triplicate.

Calculations and statistics. Concentrations given for IL-2 on the basis of biological activity refer to BRMP units. Approximative molar concentrations were calculated from the specific activity. Evoked transmitter release during superfusions was expressed as $\mathrm{pmol} \mathrm{ACh} / \mathrm{min} / \mathrm{mg}$ protein and regarded as the net transmitter release over basal efflux. The basal efflux was determined from the superfusate samples collected prior, between, as well as following periods of $\mathrm{K}^{+}$stimulations, respectively, depending on the experimental paradigm. To calculate the evoked release during a depolarization, the baseline was estimated for this period, and the values obtained for the basal efflux were subtracted from the total amount of ACh found in the superfusate. Statistical evaluations were carried out using the program NCss (parallel or paired, two-tailed) $t$ test, respectively, following $F$ test, $P<0.05$ being considered significant.

\section{Results}

Stimulation of $\mathrm{ACh}$ release from brain slices was carried out with $25 \mathrm{mM} \mathrm{KCl}$, increasing the total concentration of $\mathrm{K}^{+}$in the medium from 5.8 to $26.2 \mathrm{~mm}$. At this concentration, evoked release is known to be at submaximal level (Lipton, 1985; Pearce et al., 1991). Submaximal stimulation was regarded appropriate to reveal both drug-dependent attenuation as well as augmentation of the evoked transmitter release. Figure 1 shows the hippocampal release profile for endogenous $\mathrm{ACh}$ as determined for a stimulation period of $60 \mathrm{~min}$. The average basal release was $0.98 \pm 0.29 \mathrm{pmol} / \mathrm{min} / \mathrm{mg}$ protein (mean $\pm \mathrm{SEM}, n=98$ ). The average decline of the baseline value was determined to be $1.1 \% / \mathrm{hr}(n=18)$, demonstrating the stability and viability of the tissuc preparations under the present incubating conditions.

\section{Effects of IL-2 on hippocampal ACh release}

The effect of IL-2 on the evoked hippocampal ACh release is displayed in Table 1 for various times of tissue exposure to the interleukin. Hippocampal slices were first superfused with normal KBM for 60 min to establish the basal release. Subsequent- 


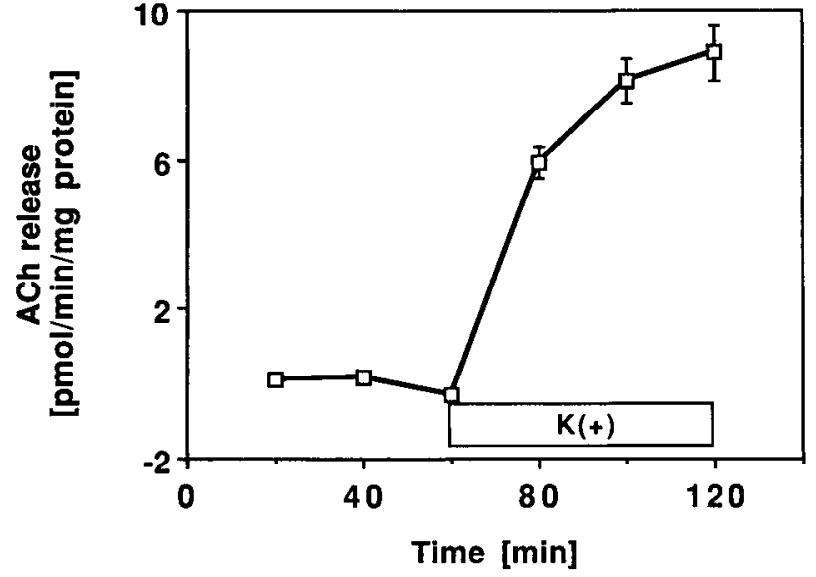

Figure 1. $\mathrm{K}^{+-}$-evoked hippocampal $\mathrm{ACh}$ release using in vitro slice superfusion. Slices were superfused with normal KBM and then stimulated for $60 \mathrm{~min}$ with $\mathrm{KBM}$ containing $25 \mathrm{mM} \mathrm{KCl}(K+)$. Data represent the mean \pm SEM of 36 superfusions.

ly, the tissue was stimulated for up to 60 min with $\mathrm{K}^{+} \mathrm{KBM}$ containing various concentrations of IL-2. The ACh release in the presence of IL-2 was compared to controls that were stimulated in the absence of IL-2.

Figure 2 represents an overlay of the concentration-response relations obtained from the various intervals of tissue stimulation, revealing the time dependency of the IL-2-mediated effects. The augmentation of ACh release by IL-2 at $1.5 \mathrm{mU} / \mathrm{ml}$ was obvious during the early period of stimulation and attenuated rapidly with time. On the contrary, the inhibition of $\mathrm{ACh}$ release by $15 \mathrm{U} / \mathrm{ml}$ IL-2 was a consistent finding even over a prolonged period of stimulation. Only tendencies toward decreased or increased values were found for 150 and $0.015 \mathrm{mU} /$ $\mathrm{ml}$ of IL-2.

During the first 20 min of $\mathrm{K}^{+}$stimulation, evoked ACh release was modulated by IL-2 in a concentration-dependent manner. At $15 \mathrm{U} / \mathrm{ml}$, IL-2 inhibited ACh release by more than $50 \%$ of the control value. At a 100 -fold lower concentration $(150 \mathrm{mU} /$ $\mathrm{ml})$, ACh release was only nonsignificantly attenuated (Fig. 2). However, when the concentration of IL-2 was further lowered to $1.5 \mathrm{mU} / \mathrm{ml}$, an increase in the amount of ACh released by a 20 min K+ KBM exposure was detected (Fig. 2). No significant

Table 1. Effect of IL-2 on the evoked release of endogenous ACh from hippocampal slices during superfusion

\begin{tabular}{|c|c|c|c|c|}
\hline \multirow{2}{*}{$\begin{array}{l}\text { Time } \\
\text { (min) }\end{array}$} & \multicolumn{4}{|l|}{ IL-2 (mU/ml) } \\
\hline & $\overline{0.015}$ & 1.5 & 150 & 15,000 \\
\hline $0-20$ & $\begin{array}{l}122.2 \pm 11.5 \\
(n=10)\end{array}$ & $\begin{array}{l}145.9 \pm 26.4 \\
(n=7)^{*}\end{array}$ & $\begin{array}{l}77.1 \pm 8.3 \\
(n=9)\end{array}$ & $\begin{array}{l}44.8 \pm 15.6 \\
(n=10)^{*}\end{array}$ \\
\hline $20-40$ & $\begin{array}{l}115.1 \pm 15.4 \\
(n=10)\end{array}$ & $\begin{array}{l}123.2 \pm 7.0 \\
(n=8)\end{array}$ & $\begin{array}{l}87.8 \pm 9.1 \\
(n=9)\end{array}$ & $\begin{array}{l}38.6 \pm 10.8 \\
(n=10)^{*}\end{array}$ \\
\hline $40-60$ & $\begin{array}{l}108.8 \pm 10.1 \\
(n=10)\end{array}$ & $\begin{array}{l}96.5 \pm 16.2 \\
(n=8)\end{array}$ & $\begin{array}{l}75.9 \pm 8.7 \\
(n=9)\end{array}$ & $\begin{array}{l}62.0 \pm 12.5 \\
(n=8)^{*}\end{array}$ \\
\hline
\end{tabular}

Data are evoked hippocampal ACh release, expressed as percentage of control, determined for various periods of tissue exposure to IL-2 in the presence of 25 $\mathrm{mM} \mathrm{KCl}$. Release over basal efflux was determined as $\mathrm{pmol} \mathrm{ACh} / \mathrm{min} / \mathrm{mg}$ protein. Data for slices treated with IL-2 were converted to percentage of the average release evoked from control slices. The data for a given concentration represent the mean $\pm \operatorname{SEM}(n)$ of two experiments.

$*, \mathrm{P}<0.05$.

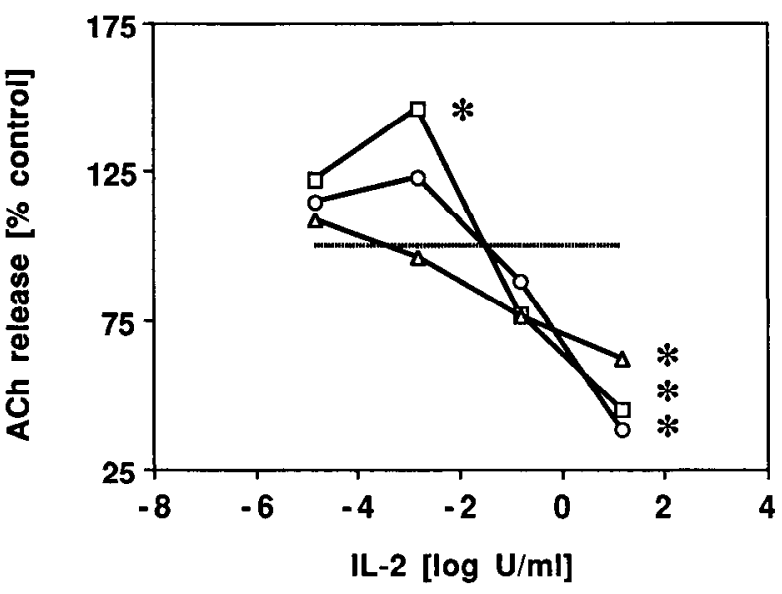

Figure 2. Effects of IL-2 on the evoked release of ACh from hippocampal slices. The dose-response curves were obtained from three intervals during tissue stimulation with $25 \mathrm{mM} \mathrm{KCl} \mathrm{( \square ,} \mathrm{0-20} \mathrm{min;} \bigcirc, 20$ $40 \mathrm{~min} ; \triangle 40-60 \mathrm{~min})$. Data are expressed as percentage of control measurements carried out in the absence of IL-2. For clarity, error bars were omitted, but values are given in Table $1 .^{*}, P<0.05$.

change was observed for the tissue samples treated with 0.015 $\mathrm{mU} / \mathrm{ml} \mathrm{IL}-2$.

During the subsequent period of stimulation, that is, the interval between 20 and 40 min, there was still a marked decrease in the evoked ACh release from slices exposed to $15 \mathrm{U} / \mathrm{ml} \mathrm{IL-2}$ (Fig. 2). With lowering the concentration of IL-2, ACh release returned to control levels. There was no longer a significant increase of evoked transmitter release for IL-2 at $1.5 \mathrm{mU} / \mathrm{ml}$.

An inhibitory effect of IL-2 was also detected during the interval between 40 and 60 min of continuous superfusion with $\mathrm{K}^{+} \mathrm{KBM}$ (Fig. 2). Almost $40 \%$ reduction in ACh release was found for chambers superfused with $15 \mathrm{U} / \mathrm{ml} \mathrm{IL-2.} \mathrm{However,}$ the IL-2 effect was significantly weaker, when compared to the period before, that is, the interval between 20 and $40 \mathrm{~min}(P<$ 0.05 in a paired $t$ test) (Fig. 2). Calculated for the total stimulation period of $60 \mathrm{~min}$, the overall evoked release was (percentage of control) $115.4,121.9,80.3$, and 48.5 for the experimental groups treated with $0.015 \mathrm{mU} / \mathrm{ml}, 1.5 \mathrm{mU} / \mathrm{ml}, 150 \mathrm{mU} /$ $\mathrm{ml}$, and $15 \mathrm{U} / \mathrm{ml} \mathrm{IL-2,} \mathrm{respectively.}$

IL-2 also inhibited ACh release when added to an ongoing stimulation. As shown in Figure 3, IL-2 at $15 \mathrm{U} / \mathrm{ml}$ transiently decreased the evoked ACh release when it was added to stimulated hippocampal slices. The profile returned to control levels after $40 \mathrm{~min}$ of IL-2 presence, equivalent to $70 \mathrm{~min}$ of continuous stimulation.

\section{Reversal of the IL-2-mediated inhibition of ACh release}

When hippocampal slices were stimulated with $\mathrm{K}^{+} \mathrm{KBM}$ for a first period of $30 \mathrm{~min}\left(S_{1}\right)$ and, following a $30 \mathrm{~min}$ rinsing with normal KBM, were stimulated a second time $\left(S_{2}, 30 \mathrm{~min}\right)$, the amounts of ACh released by $S_{1}$ and $S_{2}$ were identical (1.04 for the ratio $S_{2}: S_{1}$ ). To test whether the presence of IL-2 during $S_{1}$ would alter subsequent ACh release during $S_{2}$ in the absence of IL-2, hippocampal slices were exposed to $150 \mathrm{U} / \mathrm{ml}$ IL-2 for 30 $\mathrm{min}$ and rinsed for $30 \mathrm{~min}$, before being restimulated. The profiles in Figure 4 show that transient presence of IL-2 did not alter the efficacy of later stimulations. Consequently, toxic or permanent effects of IL-2 on the tissue could be excluded for the duration of the experiments. 


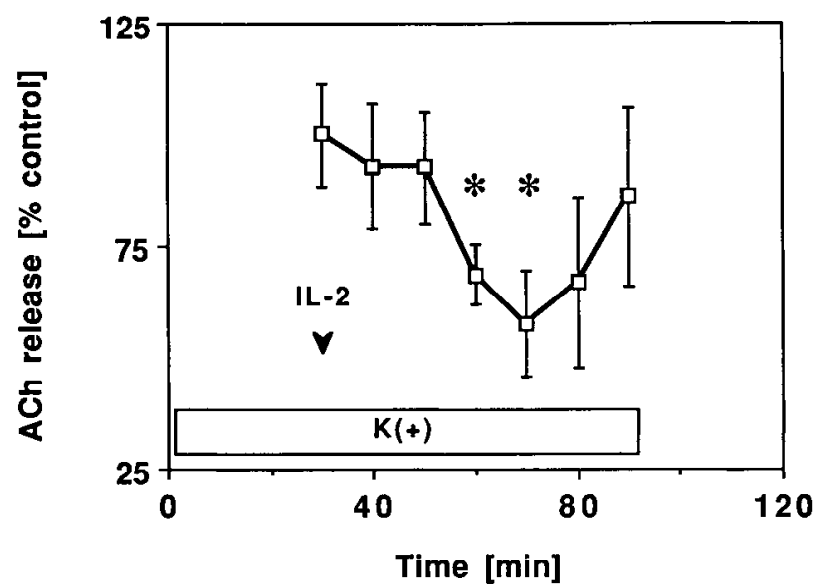

Figure 3. Effect of IL-2 on an ongoing stimulation of evoked ACh release from hippocampal slices. The tissue was stimulated with $25 \mathrm{~mm}$ $\mathrm{KCl}$ for a total period of $90 \mathrm{~min}(K+) ; 30 \mathrm{~min}$ after the onset of the stimulation IL-2 $(15 \mathrm{U} / \mathrm{ml})$ was added to the superfusion medium (arrowhead). Data are given as percentage (mean $\pm \mathrm{SEM}, n=5$ ) of untreated controls. ${ }^{*}, P<0.05$.

\section{Regional differences in the effect of $I L-2$}

Besides the hippocampal formation, IL-2 and IL-2R-associated IRM has been localized in a variety of rat brain regions, including the neostriatum and the cerebral cortex (Araujo et al., 1989; Lapchak et al., 1991). To test whether IL-2 could also modulate evoked ACh release in those regions, slices of striatum as well as of frontal and parietal cortices were superfused and $\mathrm{K}^{+}$stimulated over $60 \mathrm{~min}$ in the absence (controls) or presence of IL-2. The results are summarized in Figure 5. The average basal release was (in pmol/min/mg protein) $5.94 \pm 0.84(n=$ $32), 2.56 \pm 0.48(n=27)$, and $3.27 \pm 0.64(n=21)$ for the striatum, frontal, and parietal cortices, respectively.

IL-2 at $15 \mathrm{U} / \mathrm{ml}$ did not affect evoked ACh release in striatal tissue (Fig. $5 A$ ). The release in the presence of IL-2 was in the range between $82.1 \pm 12.2 \%$ and $126.0 \pm 20.2 \%$ when compared to the corresponding control values. Neither was there any effect of IL-2 on slices from parietal cortex; evoked ACh was between $90.2 \pm 16.6 \%$ and $98.5 \pm 13.3 \%$ of the corresponding control level (Fig. $5 C$ ). However, $15 \mathrm{U} / \mathrm{ml}$ IL-2 reduced the evoked $\mathrm{ACh}$ release from frontal cortex during the first $20 \mathrm{~min}$ of $\mathrm{K}^{+}$stimulation (Fig. $5 B$ ). The evoked release during this period was determined to be $49.8 \pm 9.9 \%(n=5)$ of the control value.

As was shown for the hippocampus, preexposure to IL-2 did not modify the subsequent release pattern in any of these other tissues (insets in Fig. $5 A-C$ ). There was thus no evidence for an altered transmitter release as a consequence of a previous incubation of the tissues with IL-2. The striatal evoked ACh release during $S_{2}$ (Fig. $5 A$ ) was $85.7 \%$ of the control amount, and $108.5 \%$ in a second experiment. When compared to the corresponding controls, ACh releases over baseline were $114.0 \%$ and $93.7 \%$ for the $S_{2}$ periods in the frontal and parietal cortices, respectively.

\section{Effects of other cytokines}

The specificity of the IL-2 effect on hippocampal ACh release was determined in slice incubations as described in Araujo et al. (1989), in the presence or absence (control) of several other

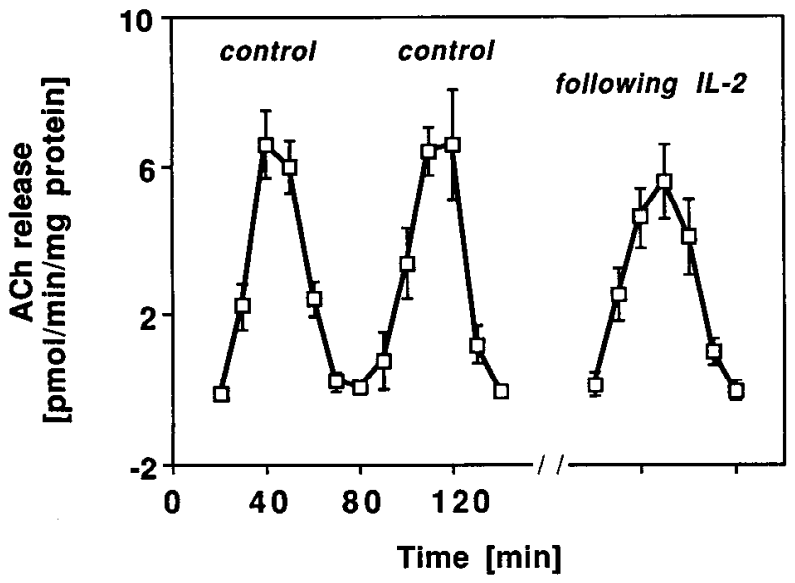

Figure 4. Evoked hippocampal $\mathrm{ACh}$ release following a transient exposure of the tissue to IL-2. Slices were stimulated for a first period of $30 \mathrm{~min}\left(S_{1}, n=11\right)$ with $25 \mathrm{~mm} \mathrm{KCl}$, rinsed for $30 \mathrm{~min}$, and stimulated a second time for $30 \mathrm{~min}\left(S_{2}\right)$. Controls showed identical amounts of released $\mathrm{ACh}$ for $S_{1}$ and $S_{2}$ (left). Another group of tissue samples ( $n=$ 6) was exposed to IL-2 $(150 \mathrm{U} / \mathrm{ml})$ during $S_{1}$. Following rinsing, the tissue was stimulated in the absence of IL-2 ( $S_{2}$ shown in the right). From the left to the right, the peak areas (corresponding to the amounts of released transmitter) were calculated to be $100.0 \%, 104.4 \%$, and $102.8 \%$. Data are given as mean \pm SEM.

cytokines. As shown in Table 2, IFN $\alpha$, IL-1 $\alpha$, IL-3, IL-5, and IL-6 did not significantly alter ACh release in this tissue. In preliminary experiments, we also observed that rat IL-2, the peptide homologous to human IL-2, modulated ACh release at $50 \mathrm{U} / \mathrm{ml}$.

\section{Discussion}

The results point to a neuromodulatory action of IL-2 on certain populations of cholinergic neurons. At a higher concentration $(15 \mathrm{U} / \mathrm{ml}, \leq 1 \mathrm{nM}), \mathrm{IL}-2$ showed a pronounced inhibition of evoked ACh release in the hippocampus and frontal cortex, while being ineffective in the striatum and parietal cortex. Interestingly, a lower concentration of IL-2 $(1.5 \mathrm{mU} / \mathrm{ml}, \leq 0.1 \mathrm{pM})$ stimulated ACh release in the hippocampal formation. It is thus evident that the effect of this cytokine on ACh release is (1) concentration dependent and (2) region specific, with terminals of selected cholinergic projections (but not striatal intrinsic neurons) being sensitive to its modulatory activity.

Modulation of $\mathrm{ACh}$ release has been reported for various agents, including muscarinic agonists and antagonists (Raiteri et al., 1984; Lapchak et al., 1989), excitatory amino acids (Scatton and Lehmann, 1982), neurotensin (Lapchak et al., 1990), and somatostatin (Araujo et al., 1990). However, micromolar concentrations of these agents are required to produce significant effects while IL-2 is effective at markedly lower concentrations $(\leq 0.1 \mathrm{pm})$ that most likely have physiological relevance. Similarly, sympathetic neurite outgrowth is optimally enhanced by $0.2-2 \mathrm{U} / \mathrm{ml} \mathrm{IL-2} \mathrm{(Haugen} \mathrm{and} \mathrm{Letourneau,} \mathrm{1990)} \mathrm{while} \mathrm{neu-}$ roendocrine effects of IL-2 were detected using picomolar to femtomolar concentrations (Karanth and McCann, 1991). II 2 , in picomolar quantities, is also known to produce soporific effects and to modulate EEG spectrum (Nisticò and De Sarro, 1991). Higher concentrations ( 200 to $\geq 3000 \mathrm{U} / \mathrm{ml}$ ) were required to block long-term potentiation (LTP) in the rat hippocampus (Tancredi et al., 1990).

For the duration of our experiments potential neurotoxic ef- 
A
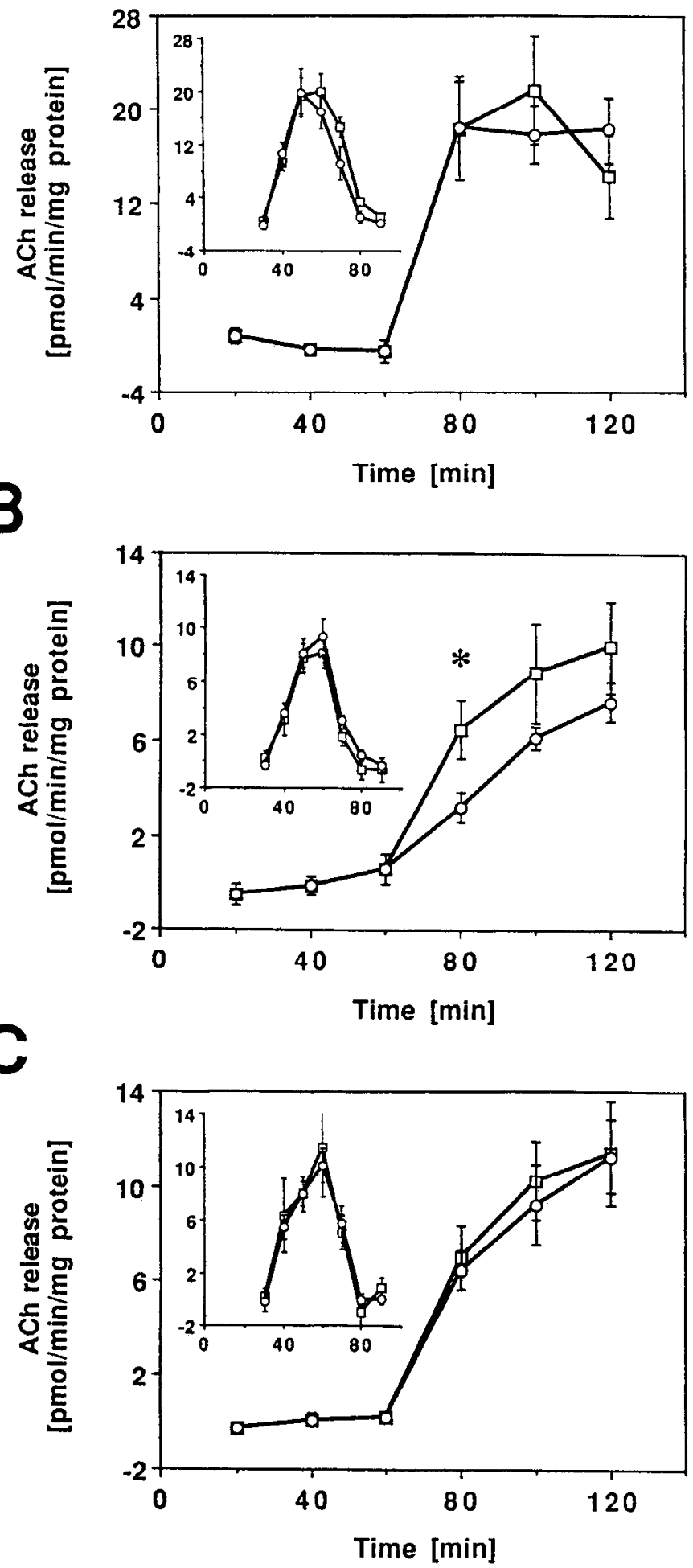

Figure 5. Effects of IL-2 on the evoked ACh release from slices of the striatum $(A, n=5)$, frontal cortex $(B, n=5)$, and parietal cortex $(C, n$ $=6$ ). Tissue slices were stimulated with $\mathrm{KBM}$ containing $25 \mathrm{mM} \mathrm{KCl}$ in the presence (O) or absence ( $\square$ ) of $15 \mathrm{U} / \mathrm{ml} \mathrm{IL-2.} \mathrm{The} \mathrm{insets} \mathrm{in} A-C$ represent the release profiles obtained with $30 \mathrm{~min}$ of $\mathrm{KCl}$ stimulation from controls ( $\square$ ) and from slices following to an exposure to IL-2 (150 $\mathrm{U} / \mathrm{ml}, \mathrm{O}$ ). Axis dimensions in the insets are the same as in the full-size graphs. For further explanation see Results. All data are given as mean \pm SEM. ${ }^{*}, P<0.05$
Table 2. $\mathbf{K}^{+}$-evoked $\mathrm{ACh}$ release from hippocampal slices incubated in the presence of various cytokines

Hippocampal ACh release (\% of control)

\begin{tabular}{lr}
\hline IFN $\alpha(5 \mathrm{nM})$ & $99.8 \pm 23.7(n=7)$ \\
IL-1 $\alpha(1 \mathrm{nM})$ & $93.3 \pm 8.2(n=8)$ \\
IL-3 $(5 \mathrm{nM})$ & $101.9 \pm 5.3(n=10)$ \\
IL-5 $(1.3 \mathrm{nM})$ & $93.5 \pm 4.0(n=10)$ \\
IL-6 $(5 \mathrm{nM})$ & $95.1 \pm 6.5(n=10)$
\end{tabular}

Total ACh release during a stimulation of $20 \mathrm{~min}$ with $25 \mathrm{~mm} \mathrm{KCl}$ was determined and expressed as percentage of the transmitter release from the corresponding controls (untreated contralateral hemispheres). The overall control value was 5.95 $\pm 0.27 \mathrm{pmol} / \mathrm{min} / \mathrm{mg}$ protein $(n=44)$. Data are given as mean $\pm \mathrm{SEM}$.

fects of IL-2 were not observed, but have been documented in neuronal cell culture following a $24 \mathrm{hr}$ exposure to IL-2 (Araujo and Cotman, 1991). In the present series of experiments, subsequent $\mathrm{ACh}$ release during $\mathrm{K}^{+}$stimulation was not altered by previous exposure to IL-2. Furthermore, over prolonged periods of stimulation in the presence of IL-2, inhibition of hippocampal evoked ACh release attenuated, being significantly less pronounced or absent after $40 \mathrm{~min}$. In the IL-2R $\alpha / \mathrm{IL}-2 \mathrm{R} \beta$ receptor complex, the $\alpha$-subunit determines the fast association with IL-2 $\left(t_{1 / 2}=37 \mathrm{sec}\right)$, whereas the $\beta$-subunit contributes to the slow dissociation of the ligand $\left(t_{1 / 2}=285 \mathrm{~min}\right)$ and to signal transduction (Kuziel and Greene, 1990; Waldmann, 1991). Similar kinetics likely apply in the CNS, the putative $k_{D}$ value (25 pM) of ${ }^{125}$ I-IL-2 binding sites (Araujo et al., 1989) being very low, rendering rapid dissociation ("washout") most unlikely. Taken all together, this suggests the termination of the IL-2 signaling by endocytosis of the ligand/receptor complex (Legrue et al., 1991). As shown in $\mathrm{YT}^{+}$cells, ${ }^{125} \mathrm{I}-\mathrm{IL}-2$ is almost completely internalized after 30-40 min incubation period (Fung et al., 1988).

While IL-2 was shown to be a very potent modulator of hippocampal ACh release, several other cytokines with established CNS activities (Plata-Salamán, 1991), that is, IFN $\alpha$, IL- $1 \alpha$, IL3 , IL-5, IL-6 (in the present study), and IL-1 $\beta$, as well as IL-4 (in Araujo et al., 1989), were ineffective, indicating that $\mathrm{ACh}$ release in the hippocampus is sensitive to a specific effect of IL-2 that is not shared by other well-known cytokines.

IL-2(-like) and IL-2R-associated (Tac antigen-like) IRM are present in the rat hippocampal formation, especially in the stratum pyramidale of the hippocampus proper as well as in the granule cell layer of the dentate gyrus (Lapchak et al., 1991). It is well known that cholinergic septal projections terminate throughout the hippocampal region, but most heavily in the strata oriens and radiatum of subfields $\mathrm{CA} 2$ and $\mathrm{CA} 3$, as well as in the infra- and supragranular zones of the dentate gyrus, making contacts with pyramidal and granule cell bodies and dendrites (Semba and Fibiger, 1989). The proximity of IL-2related IRMs and cholinergic terminals is very striking and may thus explain our functional obscrvation, that is, the modulation of ACh release by the cytokine in the hippocampal formation. On the other hand, IL-2/IL-2R-like IRM in the frontoparietal cortex concentrates within layer IV, with the staining decreasing in more caudal and ventral cortical areas (Lapchak et al., 1991). In the rat, cholinergic fibers innervating the frontoparietal cortex originate from cells in the vicinity of the substantia innominata and the ventromedial globus pallidus (Semba and Fibiger, 1989). Although some intrinsic ACh neurons exist in the cortex (layers 
II/III), the laminar pattern of cholinergic terminals predominantly arises from these projections, with high densities seen in layer V, and to a lesser extend in layer IV. It thus appears that most prominent effects of IL-2 on ACh release were observed in cortical and hippocampal areas that contain cholinergic projection terminals in proximity to IL-2/IL-2R IRM.

In contrast, IL-2 failed to modulate ACh release in the striatum, an area enriched with ACh interneurons (1-2\% of the cells; Semba and Fibiger, 1989) and detectable quantities of IL-2/IL2R IRM (Lapchak et al., 1991). This illustrates that IL-2 is not a universal modulator of ACh release, but exerts its effects in regions where IL-2-related IRM was localized in vicinity to the terminals of far-projecting $\mathrm{ACh}$ neurons.

The modulatory effect of IL-2 on ACh release, especially in the hippocampus, is of potential interest in regard to the impairments of cholinergic functions in Alzheimer's disease (AD) (Whitehouse et al., 1982; Quirion et al., 1990). In that context, it is intriguing that cholinergic neurons of the striatum, an area usually spared in AD, are insensitive to IL-2. It is also known that various markers of the immune system, such as major histocompatibility complex glycoproteins, immunoglobulin, complement, and cytokine receptors, infiltrating T-cells, cytokines, and complement factors, associated with neurodegenerative plaques and neurofibrillary tangles, are present in AD brains, implicating immune-mediated autodistruction as an important pathological event in this disorder (McGeer and Rogers, 1992). IL-2, though not being the sole candidate, could play a crucial role in the central cascading of immune-related markers, as it does in the periphery.

Regarding the biphasic profile of action observed in the hippocampus, IL-2, normally expressed in low amounts, could usually stimulate ACh release. However, under pathological conditions, levels of IL-2 are likely increased (McGeer and Rogers, 1992) and could conceivably contribute to decreased levels of $\mathrm{ACh}$ released by terminals especially in the regions primarily affected in $\mathrm{AD}$, such as the hippocampus and the frontal cortex. High concentrations of IL-2 are known to interfere with LTP in the hippocampus (Tancredi et al., 1990), an observation that could also relate to neurologic side effects associated with highdose IL-2 immunotherapies (Denicoff et al., 1987; Plata-Salamán, 1991).

Bidirectional communication between the immune system and the CNS is likely mediated by both direct cellular contacts, for example, via innervation of immunocompetent organs, and soluble factors triggering effects in remote tissues or providing humoral feedbacks (Bateman et al., 1989; De Micco, 1989; Dunn, 1989; Jankovic, 1989; Rabin et al., 1989; Sternberg, 1989; Merrill, 1990; Plata-Salamán, 1991). Some of these mediators can be produced by cells of both systems, obliterating the "classical" demarcation between immuno- and neuroregulators. Immunoregulators likely play pivotal roles in normal CNS development and function, in the induction and coordination of posttraumatic events (Plata-Salamán, 1991; Hall and Rao, 1992), and probably in pathogenetic processes associated with neurologic disorders (Blume and Vitek, 1989; Matsuyama et al., 1991; Vandenabeele and Fiers, 1991; McGeer and Rogers, 1992; Royston et al., 1992). Upon challenge of an immune or inflammatory response or during cytokine-based immunotherapy, cytokines may become more active in the CNS, provided that they have access to functionally coupled receptors in the brain. In the case of IL-2, evidence has been reported that fulfills these predictions. However, it remains to be shown whether other factors known to be induced by IL-2, such as tumor necrosis factor, are partly responsible for effects ascribed to IL-2 (Ellison and Merchant, 1991). It is thus of great interest to determine whether the modulatory action of this cytokine on cholinergic nerve terminals is due to a direct effect or whether it involves other mediators.

\section{References}

Alexander JT, Saris SC, Oldfield EH (1989) The effect of interleukin-2 on the blood-brain barrier in the $9 \mathrm{~L}$ gliosarcoma rat model. $\mathrm{J}$ Neurosurg 70:92-96.

Araujo DM, Cotman CW (1991) Effects of lymphokines on glial and neuronal cells in vitro: a role for lymphokines as modulators of neuralglial interactions. Soc Neurosci Abstr 17:475.19.

Araujo DM, Lapchak PA, Collier B, Quirion R (1989) Localization of interleukin-2 immunoreactivity and interleukin-2 receptors in the rat brain: interaction with the cholinergic system. Brain Res 498:257266.

Araujo DM, Lapchak PA, Collier B, Quirion R (1990) Evidence that somatostatin enhances endogenous acetylcholine release in the hippocampus. J Neurochem 55:1546-1555.

Banks WA, Ortiz L, Plotkin SR, Kastin AJ (1991) Human interleukin (IL) $1 \alpha$, murine IL- $1 \alpha$ and murine IL- $1 \beta$ are transported from blood to brain in the mouse by a shared saturable mechanism. J Pharmacol Exp Ther 259:988-996.

Bateman A, Singh A, Kral T, Solomon S (1989) The immune-hypothalamic-pituitary-adrenal axis. Endocr Rev 10:92-112.

Blume AJ, Vitek MP (1989) Focusing on IL-1-promotion of $\beta$-amyloid precursor protein synthesis as an early event in Alzheimer's disease. Neurobiol Aging 10:406-408.

De Micco C (1989) Immunology of central nervous system tumors. J Neuroimmunol 25:93-108.

Denicoff KD, Rubinow DR, Papa MZ, Simpson C, Seipp CA, Lotze MT, Chang AE, Rosenstein D, Rosenberg DA (1987) The neuropsychiatric effects of treatment with interleukin-2 and lymphokine activated killer cells. Ann Intern Med 107:293-300.

Dunn AJ (1989) Psychoneuroimmunology for the psychoneuroendocrinologist: a review of animal studies of nervous system-immune system interactions. Psychoneuroendocrinology 14:251-274.

Ellison MD, Merchant RE (1991) Appearance of cytokine-associated central nervous system myelin damage coincides temporally with serum tumor necrosis factor induction after recombinant interleukin-2 infusion in rats. J Neuroimmunol 33:245-251.

Ellison MD, Povlishock JT, Merchant RE (1987) Blood-brain barrier dysfunction in cats following recombinant interleukin-2 infusion. Cancer Res 47:5765-5770.

Ellison MD, Krieg RJ, Povlishock JT (1990) Differential central nervous system responses following single and multiple recombinant interleukin-2 infusions. J Neuroimmunol 28:249-260.

Fung MR, Ju G, Greene WC (1988) Co-internalization of the p55 and p70 subunits of the high-affinity human interleukin 2 receptor: evidence for a stable ternary receptor complex. J Exp Med 168:19231928.

Goldberg AM, McCaman RE (1973) The determination of picomole amounts of acetylcholine in mammalian brain. J Neurochem 20:1-8.

Hall AK, Rao MS (1992) Cytokines and neurokines: related ligands and related receptors. Trends Neurosci 15:35-37.

Hatekayama M, Taniguchi T (1991) Interleukin-2. In: Peptide growth factors and their receptors, Vol 1 (Sporn MB, Roberts AB, eds), pp 523-540. New York: Springer.

Haugen PK, Letourneau PC (1990) Interleukin-2 enhances chick and rat sympathetic, but not sensory, neurite outgrowth. J Neurosci Res 25:443-452.

Jankovic BD (1989) Neuroimmunomodulation: facts and dilemmas. Immunol Lett 21:101-118.

Karanth S, McCann SM (1991) Anterior pituitary hormone control by interleukin 2. Proc Natl Acad Sci USA 88:2961-2965.

Kuziel WA, Greene WC (1990) Interleukin-2 and the IL-2 receptor: new insights into structure and function. J Invest Dermatol 94:27S$32 \mathrm{~S}$.

Lapchak PA, Araujo DM, Quirion R, Collier B (1989) Binding sites for $\left[{ }^{3} \mathrm{H}\right] \mathrm{AF}-\mathrm{DX} 116$ and effect of AF-DX 116 on endogenous acetylcholine release from rat brain slices. Brain Res 496:285-294. 
Lapchak PA, Araujo DM, Quirion R, Beaudet A (1990) Neurotensin regulation of endogenous acetylcholine release from rat cerebral cortex: effect of quinolinic acid lesions of the basal forebrain. J Neurochem 55:1397-1403.

Lapchak PA, Araujo DM, Quirion R, Beaudet A (1991) Immunoautoradiographic localization of interleukin 2-like immunoreactivity and interleukin 2 receptors (Tac antigen-like immunoreactivity) in the rat brain. Neuroscience 44:173-184.

Legrue SJ, Sheu TL, Chernajovsky Y (1991) The role of receptorligand endocytosis and degradation in interleukin-2 signaling and T-lymphocyte proliferation. Lymphokine Cytokine Res 10:431-436.

Lipton P (1985) Brain slices. In: General neurochemical techniques, neuromethods, Ser 1, Neurochemistry (Boulton AA, Baker GB, eds), pp 69-1 15. Clifton, NJ: Humana.

Lowry OH, Rosebrough NJ, Farr AL, Randall RJ (1951) Protein measurement with the Folin phenol reagent. J Biol Chem 193:265275.

Luber-Narod J, Rogers J (1988) Immune system associated antigens expressed by cells of the human central nervous system. Neurosci Lett 94:17-22.

Matsuyama T, Kobayashi N, Yamamoto N (1991) Cytokines and HIV infection: is AIDS a tumor necrosis factor disease? Aids 5:1405-1417.

McGeer PL, Rogers J (1992) Anti-inflammatory agents as a therapeutic approach to Alzheimer's disease. Neurology 42:447-449.

Merrill JE (1990) Interleukin-2 effects in the central nervous system. Ann NY Acad Sci 594:188-199.

Merrill JE (1991) Bellini, Carpaccio, and receptors in the central nervous system. J Cell Biochem 46:191-198.

Nieto-Sampedro M, Chandy KG (1987) Interleukin-2-like activity in injured brain. Neurochem Res 12:723-727.

Nisticò G, De Sarro G (1991) Is interleukin 2 a neuromodulator in the brain? Trends Neurosci 14:146-150.

Pearce LB, Buck T, Adamec E (1991) Rapid kinetics of potassiumevoked release of acetylcholine from rat brain synaptosomes: analysis by rapid superfusion. J Neurochem 57:636-647.

Plata-Salamán CR (1991) Immunoregulators in the nervous system. Neurosci Biobehav Rev 15:185-215.

Quirion R, Aubert I, Robitaille Y, Gauthier S, Araujo D, Chabot JG (1990) Neurochemical deficits in pathological brain aging: specificity and possible relevance for treatment strategies. Clin Neuropharmacol 13[Suppl 3]:73-80.

Rabin BS, Cohen S, Ganguli R, Lysle DT, Cunnick JE (1989) Bidirectional interaction between the central nervous system and the immune system. Crit Rev Immunol 9:279-312.
Raiteri M, Leardi R, Marchi M (1984) Heterogeneity of presynaptic muscarinic receptors regulating neurotransmitter release in rat brain. J Pharmacol Exp Ther 228:209-214

Richter JA (1976) Characteristics of acetylcholine release by superfused slices of rat brain. J Neurochem 26:791-797.

Rosenberg SA (1990) Adoptive immunotherapy for cancer. Sci Am 262(5):62-69.

Royston MC, Rothwell NJ, Roberts GW (1992) Alzheimer's disease: pathology to potential treatments? Trends Pharmacol Sci 13:131-133.

Saris SC, Rosenberg A, Friedman RB, Rubin JT, Barba D, Oldfield EH (1988) Penetration of recombinant interleukin-2 across the bloodcerebrospinal fluid barrier. J Neurosurg 69:29-34.

Scatton B, Lehmann J (1982) $N$-methyl-D-aspartate-type receptors mediate striatal ${ }^{3} \mathrm{H}$-acetylcholine release evoked by excitatory amino acids. Nature 297:422-424.

Semba K, Fibiger HC (1989) Organization of central cholinergic systems. In: Progress in brain research, Vol 79, Nicotinic receptors in the CNS: their role in synaptic transmission. (Nordberg A, Fuxe K, Holmstedt B, Sundwall A), pp 37-63. Amsterdam: Elsevier.

Seto D, Hanisch UK, Chabot JG, Quirion R (1991) Evoked efflux of endogenous acetylcholine from rat brain slices: effect of interleukin2. Soc Neurosci Abstr 17:313.13.

Sternberg EM (1989) Monokines, lymphokines, and the brain. In: The year in immunology, Vol 5, Immunoregulatory cytokines and cell growth (Cruse JM, Lewis RE, eds), pp 205-217. Basel: Karger.

Tancredi V, Zona C, Velotti F, Eusebi F, Santoni A (1990) Interleukin-2 suppresses established long-term potentiation and inhibits its induction in the rat hippocampus. Brain Res 525:149-151.

Vandenabeele $P$, Fiers W (1991) Is amyloidogenesis during Alzheimer's disease due to an IL-1-/IL-6-mediated 'acute phase response' in the brain? Immunol Today 12:217-219.

Villemain F, Owens T, Renno T, Beaudet A (1991) Localization of mRNA for interleukin-2 (IL-2) in mouse brain by in situ hybridization. Soc Neurosci Abstr 17:475.20.

Waldmann TA (1991) The interleukin-2 receptor. J Biol Chem 266: 2681-2684

Watts RG, Wright JL, Atkinson LL, Merchant RE (1989) Iistopathological and blood-brain barrier changes in rats induced by an intracerebral injection of human interleukin 2. Neurosurgery 25:202-208.

Whitehouse PJ, Price DL, Struble RG, Clark AW, Coyle JT, DeLong MR (1982) Alzheimer's disease and senile dementia: loss of neurons in the basal forebrain. Science 215:1237-1239. 